\title{
35. A STREAMLINED FORAMINIFERAL TRANSFER FUNCTION FOR THE SUBPOLAR NORTH ATLANTIC 1
}

\author{
William F. Ruddiman, Lamont-Doherty Geological Observatory and Department of Geological Sciences, \\ Columbia University \\ and \\ Ann Esmay, Lamont-Doherty Geological Observatory²
}

\begin{abstract}
A new foraminifer-based transfer function permits substantially faster rates of sample counting in the subpolar North Atlantic. This is achieved by reducing to four the number of planktonic foraminiferal species recognized and by quantifying all others as a fifth group. Although the new equation gives standard errors of estimate against atlas values that are $50 \%$ larger for the summer and winter seasons than those from equation F13 of Kipp (1976), it still matches in considerable detail all major downcore sea-surface temperature trends estimated from a variant of equation F13 introduced by Ruddiman and Glover (1975) in two conventional piston cores and the record from one DSDP hole cored with the hydraulic piston corer. Spectral analyses of sea-surface temperature signals based on the new equation also closely reproduce orbital rhythms previously found in two North Atlantic cores. The new equation is applicable to cores located north of $40^{\circ} \mathrm{N}$ and to records spanning most of the Pleistocene Era. Acceptable precision can be maintained with as few as 200 to 250 individuals counted.
\end{abstract}

\section{INTRODUCTION}

Analytical techniques suitable for conventional piston cores $10 \mathrm{~m}$ in length may be too slow to process much longer sections from hydraulic piston coring (HPC). In particular, there is a need for more rapid census counts to derive sea-surface temperature (SST) estimates from transfer functions, although this is balanced by the constraint of maintaining adequate accuracy and precision. Widely used North Atlantic transfer function F13 (Kipp, 1976) requires counts of all planktonic foraminifers larger than $150 \mu \mathrm{m}$ in aliquots of $\mathbf{3 0 0}$ or more individuals, usually at the rate of about two samples per day (not including preparation time). Our goal in this study was to improve the counting rate of Pleistocene samples in the subpolar North Atlantic without sacrificing critical paleoenvironmental information. The key to this improvement lies in reducing the number of species counted, particularly the subtle taxonomic intergrades that slow the counting process.

\section{MEASURES OF EQUATION PERFORMANCE}

We ran numerous tests in developing the new transfer function (Table 1). For each test, we used two basic measures of equation performance: (1) ability to use counts of foraminiferal assemblages in core tops to reproduce modern atlas SST values (Table 2); and (2) ability to match previously estimated SST values in downcore records (Table 2). For the core-top work, transfer function F13 of Kipp (1976) was the standard for evaluating ac-

\footnotetext{
${ }^{1}$ Ruddiman, W. F., Kidd, R. B., Thomas, E., et al., Init. Repts. DSDP, 94: Washington (U.S. Govt. Printing Office).

2 Addresses: (Ruddiman) Lamont-Doherty Geological Observatory, Palisades, NY 10964 and Department of Geological Sciences, Columbia University, New York, NY; (Esmay) Lamont-Doherty Geological Observatory, Palisades, NY 10964.
}

ceptable performance. For the downcore comparisons, each new equation was tested against a slightly altered version of F13 introduced by Ruddiman and Glover (1975) and designated here as $\mathrm{F} 13^{\prime}$.

For most of the tests run on surface-sediment assemblages, we used the standard procedures for deriving transfer functions (Imbrie et al., 1973). These include: factor analysis, regression of the factors against atlas values of SST, estimation of SST at each site, and calculation of multiple correlation coefficients and standard errors of estimate. Table 2 lists for each equation tested the seasonal standard errors of estimate and multiple correlation coefficients, the two most commonly used measures of equation performance.

For the downcore testing, we used North Atlantic Piston Cores V30-97 and K708-7 (Fig. 1). Ruddiman and McIntyre $(1981,1984)$ published detailed records of estimated SST over the last $250,000 \mathrm{yr}$. in both cores based on equation $\mathrm{F}^{\prime} 3^{\prime}$. These cores were chosen because their upper Quaternary records encompass the range of assemblages likely to be found in the Pleistocene of the mid- to high-latitude North Atlantic. The records also clearly portray important aspects of the rhythmic response of the subpolar ocean to orbital forcing: the strong 100,000 -yr. cycle in both records; the modest 41,000 -yr. signal in K708-7; and the very strong 23,000 -yr. signal in V30-97 (Ruddiman and McIntyre, 1984). For Core K708-7, we actually based the downcore comparison on a much longer record spanning the last 0.69 m.y., but showing rhythmic characteristics generally similar to the shorter 0.25 -m.y. segment, except for somewhat diminished 41,000-yr. power (Ruddiman et al., 1986). We judged it critical that the new transfer function reproduce the orbital rhythms in these cores. There is, however, no "ground truth" such as atlas SST temperature values against which to judge equation performance downcore, 
Table 1. Description of tests made during development of equation F13 $\times 5$.

\begin{tabular}{|c|c|c|c|c|c|c|c|c|c|c|c|c|}
\hline \multirow[b]{2}{*}{ Test } & \multirow[b]{2}{*}{$\begin{array}{l}\text { Number of } \\
\text { core-tops } \\
\text { analyzed }\end{array}$} & \multirow{2}{*}{$\begin{array}{l}\text { Geographic } \\
\text { cutoff: } \\
\text { southern } \\
\text { limit }\end{array}$} & \multicolumn{5}{|c|}{ Species used } & \multirow[b]{2}{*}{ Oth } & \multicolumn{3}{|c|}{ Factor analysis } & \multirow[b]{2}{*}{$\begin{array}{c}\text { Regression } \\
\text { analysis }\end{array}$} \\
\hline & & & $\begin{array}{l}\text { No. } \\
\text { sp. }\end{array}$ & $\underset{r u b}{G .}$ & $\begin{array}{l}\text { G. } \\
\text { bul }\end{array}$ & $\begin{array}{l}N . \\
p a c\end{array}$ & $\begin{array}{l}G \text {. } \\
\text { inf }\end{array}$ & & $\begin{array}{c}\text { Use } \\
\text { factor } \\
\text { analysis? }\end{array}$ & $\begin{array}{c}\text { Number } \\
\text { of } \\
\text { factors }\end{array}$ & $\begin{array}{l}\text { Use \%range } \\
\text { transformation? }\end{array}$ & \\
\hline 1 & 191 & None & 4 & $\mathrm{x}$ & $\mathrm{x}$ & $\mathrm{x}$ & $\mathrm{x}$ & & Yes & 3 & No & POW \\
\hline 2 & 191 & None & 5 & $\mathrm{x}$ & $\mathrm{x}$ & $\mathrm{x}$ & $\mathrm{x}$ & $\mathrm{x}$ & Yes & 4 & No & POW \\
\hline 3 & 119 & $28^{\circ} \mathrm{N}$ & 5 & $x$ & $x$ & $x$ & $\mathrm{x}$ & $\mathrm{x}$ & Yes & 4 & No & POW \\
\hline 4 & 111 & $30^{\circ} \mathrm{N}$ & 5 & $\mathrm{x}$ & $\mathrm{x}$ & $\ddot{x}$ & $\mathrm{x}$ & $\mathrm{x}$ & Yes & 4 & No & POW \\
\hline 5 & 124 & $25^{\circ} \mathrm{N}$ & 5 & $\mathrm{x}$ & $\mathrm{x}$ & $\mathrm{x}$ & $\mathrm{x}$ & $\mathrm{x}$ & Yes & 4 & No & POW \\
\hline 6 & 124 & $25^{\circ} \mathrm{N}$ & 4 & $x$ & & $x$ & $\mathrm{x}$ & $\mathrm{x}$ & Yes & 3 & No & POW \\
\hline 7 & 124 & $25^{\circ} \mathrm{N}$ & 4 & $\mathrm{x}$ & $\mathrm{x}$ & $\ddot{x}$ & & $\mathrm{x}$ & Yes & 3 & No & POW \\
\hline 8 & 124 & $25^{\circ} \mathrm{N}$ & 3 & $x$ & & $x$ & & $\mathrm{x}$ & $\mathrm{NF}$ & - & - & - \\
\hline 9 & 124 & $25^{\circ} \mathrm{N}$ & $7 *$ & $\mathrm{x}$ & $x$ & $\mathrm{x}$ & $x$ & $\mathrm{x}$ & Yes & 4 & No & POW \\
\hline 10 & 124 & $25^{\circ} \mathrm{N}$ & 5 & $\mathrm{x}$ & $\mathrm{x}$ & $\mathrm{x}$ & $\mathrm{x}$ & $\mathrm{x}$ & Yes & 4 & Yes & POW \\
\hline 11 & 124 & $25^{\circ} \mathrm{N}$ & 5 & $\mathrm{x}$ & $\mathrm{x}$ & $\mathrm{x}$ & $\mathrm{x}$ & $\mathrm{x}$ & Yes & 4 & No & LIN \\
\hline 12 & 124 & $25^{\circ} \mathrm{N}$ & 5 & $\mathrm{x}$ & $\mathrm{x}$ & $\mathrm{x}$ & $\mathrm{x}$ & $\mathrm{x}$ & Yes & 4 & Yes & LIN \\
\hline 13 & 124 & $25^{\circ} \mathrm{N}$ & 4 & 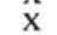 & & $\mathrm{x}$ & $\mathrm{x}$ & $\mathrm{x}$ & Yes & 3 & Yes & POW \\
\hline 14 & 124 & $25^{\circ} \mathrm{N}$ & 4 & $x$ & & $\mathrm{x}$ & $\mathrm{x}$ & $x$ & Yes & 3 & No & LIN \\
\hline 15 & 124 & $25^{\circ} \mathrm{N}$ & 4 & $\mathrm{x}$ & & $\mathrm{x}$ & $\mathrm{x}$ & $\mathrm{x}$ & Yes & 3 & Yes & LIN \\
\hline 16 & 117 & $\begin{array}{l}25^{\circ} \mathrm{N}: \mathrm{W} / \mathrm{C} \\
35^{\circ} \mathrm{N}: \mathrm{E}\end{array}$ & 5 & $\mathrm{x}$ & $\mathrm{x}$ & $\mathrm{x}$ & $\mathrm{x}$ & $\mathrm{x}$ & Yes & 4 & No & POW \\
\hline 17 & 114 & $\begin{array}{l}25^{\circ} \mathrm{N}: \mathrm{E} / \mathrm{C} \\
35^{\circ} \mathrm{N}: \mathrm{W}\end{array}$ & 5 & $\mathrm{x}$ & $\mathrm{x}$ & $\mathrm{x}$ & $\mathrm{x}$ & $\mathrm{x}$ & Yes & 4 & No & POW \\
\hline 18 & 119 & $\begin{array}{l}25^{\circ} \mathrm{N} \text { plus } \\
38-42^{\circ} \mathrm{N}: \mathrm{W}\end{array}$ & 5 & $\mathrm{x}$ & $\mathrm{x}$ & $\mathrm{x}$ & $\mathrm{x}$ & $\mathrm{x}$ & Yes & 4 & No & POW \\
\hline 19 & 107 & $\begin{array}{l}25^{\circ} \mathrm{N}: \mathrm{C} \\
35^{\circ} \mathrm{N}: \mathrm{E} / \mathrm{W}\end{array}$ & 5 & $\mathrm{x}$ & $\mathrm{x}$ & $\mathrm{x}$ & $\mathrm{x}$ & $\mathrm{x}$ & Yes & 4 & No & POW \\
\hline 20 & 112 & $\begin{array}{l}25^{\circ} \mathrm{N}: \mathrm{W} / \mathrm{C} \\
35^{\circ} \mathrm{N}: \mathrm{E} \text { plus } \\
38-42^{\circ} \mathrm{N}: \mathrm{W}\end{array}$ & 5 & $\mathrm{x}$ & $\mathrm{x}$ & $\mathrm{x}$ & $\mathrm{x}$ & $\mathrm{x}$ & Yes & 4 & No & POW \\
\hline 21 & 109 & $\begin{array}{l}25^{\circ} \mathrm{N}: \mathrm{E} / \mathrm{C} \\
35^{\circ} \mathrm{N}: \mathrm{W} \text { plus } \\
38-42^{\circ} \mathrm{N}: \mathrm{W}\end{array}$ & 5 & $\mathrm{x}$ & $\mathrm{x}$ & $\mathrm{x}$ & $\mathrm{x}$ & $\mathrm{x}$ & Yes & 4 & No & POW \\
\hline 22 & 102 & $\begin{array}{l}25^{\circ} \mathrm{N}: \mathrm{C} \\
35^{\circ} \mathrm{N}: \mathrm{E} / \mathrm{W} \text { plus } \\
38-42^{\circ} \mathrm{N}: \mathrm{W}\end{array}$ & 5 & $\mathrm{x}$ & $\mathrm{x}$ & $\mathrm{x}$ & $\mathrm{x}$ & $\mathrm{x}$ & Yes & 4 & No & POW \\
\hline 23 & 124 & $25^{\circ} \mathrm{N}$ & 4 & $\mathrm{x}$ & $\mathrm{x}$ & $\mathrm{x}$ & $\mathrm{x}$ & & Yes & 3 & No & POW \\
\hline 24 & 105 & $32^{\circ} \mathrm{N}$ & 5 & $\mathrm{x}$ & $\mathrm{x}$ & $\mathrm{x}$ & $\mathrm{x}$ & $\mathrm{x}$ & Yes & 4 & No & POW \\
\hline 25 & 124 & $25^{\circ} \mathrm{N}$ & 4 & & $\mathrm{x}$ & $\mathrm{x}$ & $\mathrm{x}$ & $\mathrm{x}$ & Yes & 3 & No & POW \\
\hline 26 & 126 & $\begin{array}{l}22^{\circ} \mathrm{N}: \mathrm{W} / \mathrm{C} \\
35^{\circ} \mathrm{N}: \mathrm{E}\end{array}$ & 5 & $\mathrm{x}$ & $\mathrm{x}$ & $\mathrm{x}$ & $\mathrm{x}$ & $\mathrm{x}$ & Yes & 4 & No & POW \\
\hline 27 & 124 & $25^{\circ} \mathrm{N}$ & 5 & $\mathrm{x}$ & $\mathrm{x}$ & $\mathrm{x}$ & $\mathrm{x}$ & $\mathrm{x}$ & Yes & 3 & No & POW \\
\hline 28 & 119 & $28^{\circ} \mathrm{N}$ & 5 & $\mathrm{x}$ & $\mathrm{x}$ & $\mathrm{x}$ & $\mathrm{x}$ & $\mathrm{x}$ & Yes & 3 & No & POW \\
\hline 29 & 111 & $30^{\circ} \mathrm{N}$ & 5 & $\mathrm{x}$ & $\mathrm{x}$ & $\mathrm{x}$ & $\mathrm{x}$ & $\mathrm{x}$ & Yes & 3 & No & POW \\
\hline 30 & 124 & $25^{\circ} \mathrm{N}$ & 3 & $\mathrm{x}$ & & $\mathrm{x}$ & $\mathrm{x}$ & & Yes & 3 & No & POW \\
\hline 31 & 111 & $30^{\circ} \mathrm{N}$ & 5 & $\mathrm{C}$ & $\mathrm{x}$ & $\mathrm{x}$ & $\mathrm{x}$ & $\mathrm{x}$ & Yes & 4 & No & POW \\
\hline 32 & 111 & $30^{\circ} \mathrm{N}$ & 5 & $\mathrm{C}$ & $\mathrm{x}$ & $\mathrm{x}$ & $\mathrm{x}$ & $\mathrm{x}$ & Yes & 4 & Yes & POW \\
\hline 33 & 111 & $30^{\circ} \mathrm{N}$ & 5 & $\mathrm{~s}$ & $\mathrm{x}$ & $\mathrm{x}$ & $\mathrm{x}$ & $\mathrm{x}$ & Yes & 4 & Yes & POW \\
\hline 34 & 124 & $25^{\circ} \mathrm{N}$ & 3 & $\mathrm{X}$ & & $\mathrm{x}$ & $\mathrm{x}$ & & No & - & - & LIN \\
\hline 35 & 124 & $25^{\circ} \mathrm{N}$ & 4 & $\mathrm{x}$ & $\mathrm{x}$ & $\mathrm{x}$ & $\mathrm{x}$ & & No & - & - & LIN \\
\hline 36 & 119 & $\begin{array}{l}30^{\circ} \mathrm{N}: \mathrm{W} / \mathrm{C} \\
25^{\circ} \mathrm{N}: \mathrm{C} / \mathrm{E}\end{array}$ & 5 & $\mathrm{x}$ & $\mathrm{X}$ & $\mathrm{x}$ & $\mathrm{x}$ & $\mathrm{x}$ & Yes & 4 & No & POW \\
\hline 37 & 129 & $\begin{array}{l}30^{\circ} \mathrm{N}: \mathrm{W} / \mathrm{C} \\
10^{\circ} \mathrm{N}: \mathrm{C} / \mathrm{E}\end{array}$ & 5 & $\mathrm{x}$ & $\mathrm{x}$ & $\mathrm{x}$ & $\mathrm{x}$ & $\mathrm{x}$ & Yes & 4 & No & POW \\
\hline 38 & 111 & $30^{\circ} \mathrm{N}$ & 5 & C & $\mathrm{x}$ & $\mathrm{x}$ & $x$ & $\mathrm{x}$ & Yes & 4 & Yes & LIN \\
\hline 39 & 111 & $30^{\circ} \mathrm{N}$ & 5 & C & $\mathrm{x}$ & $\hat{x}$ & $\mathrm{x}$ & $\mathrm{x}$ & No & - & - & LIN \\
\hline 40 & 138 & $\begin{array}{l}32^{\circ} \mathrm{N}: \mathrm{W} \text { to } \\
10^{\circ} \mathrm{N}: \mathrm{E}\end{array}$ & 5 & $\mathrm{x}$ & $\mathrm{x}$ & $\mathrm{x}$ & $\mathrm{x}$ & $\mathrm{x}$ & Yes & 4 & No & POW \\
\hline 41 & 132 & $\begin{array}{l}32^{\circ} \mathrm{N}: \mathrm{W} \text { to } \\
20^{\circ} \mathrm{N}: \mathrm{C} \\
20^{\circ} \mathrm{N}: \mathrm{C} / \mathrm{E}\end{array}$ & 5 & $x$ & $\mathrm{x}$ & $x$ & $x$ & $x$ & Yes & 4 & No & POW \\
\hline 42 & 124 & $25^{\circ} \mathrm{N}$ & 5 & $\mathrm{x}$ & $x$ & $\mathrm{x}$ & $\mathrm{x}$ & $\mathrm{x}$ & No & - & - & LIN \\
\hline 43 & 124 & $25^{\circ} \mathrm{N}$ & 4 & $\mathrm{x}$ & & $\mathrm{x}$ & $\mathrm{x}$ & $\mathrm{x}$ & No & - & - & LIN \\
\hline
\end{tabular}

Note: For geographic cutoff: $\mathrm{W}=$ west, $\mathrm{E}=$ east, $\mathrm{C}=$ central. For variable southern limit, latitudes in each sector (W, E, and $\mathrm{C}$ ) are specified. For species used: No. sp. = number of species analyzed, $\mathrm{X}=\%$ species, $\mathrm{C}=$ cube root of $\%$ species, $\mathrm{S}=$ square root of $\%$ species, $*=G$. truncatulinoides (dextral and sinistral) varieties used. Species abbreviations: G.rub $=G$. ruber (white), G.bull $=G$. bulloides, N.pac $=N$. pachyderma $($ s., sinistral), G.inf $=G$. inflata, Oth $=$ other. For factor analysis: NF $=$ will not factor. For regression analysis: $\mathrm{LIN}=$ linear regression, $\mathrm{POW}=$ curvilinear regression. Dash indicates not applicable.

only the match of each test equation to the F13' standard.

To evaluate the downcore performance of the test equations, we report for each season in each core a measure of the difference between downcore SST estimates made by equation F13' and those made by the test equations
(Table 2). We also list in Table 2 the mean SST offsets between each test equation and $\mathrm{F} 13^{\prime}$.

In addition, we later compare SST estimates from the chosen equation and from $\mathrm{F}^{\prime} 3^{\prime}$ in a segment of Hole $552 \mathrm{~A}$ (Fig. 1) dated at 0.65 to $1.0 \mathrm{Ma}$ (Shackleton et al., 1984). This older record was chosen to assess whether 
Table 2. Statistical evaluations of equation performance on core tops and downcore (temperature in ${ }^{\circ} \mathrm{C}$ ).

\begin{tabular}{|c|c|c|c|c|c|c|c|c|c|c|c|c|}
\hline \multirow[b]{4}{*}{ Test } & \multicolumn{4}{|c|}{ Equation statistics $^{\mathrm{a}}$} & \multicolumn{8}{|c|}{ Downcore statistics: residuals $\left(\mathrm{F} 13^{\prime}-\mathrm{F} 13 \times 5\right)$} \\
\hline & & & \multirow{2}{*}{\multicolumn{2}{|c|}{ SSTw }} & \multicolumn{4}{|c|}{ V30-97 } & \multicolumn{4}{|c|}{ K708-7 } \\
\hline & \multicolumn{2}{|c|}{ SSTs } & & & \multicolumn{2}{|c|}{ SSTs } & \multicolumn{2}{|c|}{ SSTw } & \multicolumn{2}{|c|}{ SSTs } & \multicolumn{2}{|c|}{ SSTw } \\
\hline & $\begin{array}{l}\text { Standard } \\
\text { error of } \\
\text { estimate }\end{array}$ & $\begin{array}{l}\text { Multiple } \\
\text { correlation } \\
\text { coefficient }\end{array}$ & $\begin{array}{l}\text { Standard } \\
\text { error of } \\
\text { estimate }\end{array}$ & $\begin{array}{l}\text { Multiple } \\
\text { correlation } \\
\text { coefficient }\end{array}$ & $\begin{array}{l}\text { Mean of } \\
\text { residuals }\end{array}$ & $\begin{array}{l}\text { Measure } \\
\text { of } \\
\text { difference }\end{array}$ & $\begin{array}{l}\text { Mean of } \\
\text { residuals }\end{array}$ & $\begin{array}{l}\text { Measure } \\
\text { of } \\
\text { difference }\end{array}$ & $\begin{array}{l}\text { Mean of } \\
\text { residuals }\end{array}$ & $\begin{array}{l}\text { Measure } \\
\text { of } \\
\text { difference }\end{array}$ & $\begin{array}{l}\text { Mean of } \\
\text { residuals }\end{array}$ & $\begin{array}{c}\text { Measure } \\
\text { of } \\
\text { difference }\end{array}$ \\
\hline 1 & 1.806 & 0.972 & 2.114 & 0.968 & -1.60 & 2.39 & -1.25 & 1.68 & -0.75 & 1.66 & -1.09 & 1.76 \\
\hline 2 & 2.105 & 0.962 & 2.112 & 0.969 & -1.40 & 3.47 & -1.28 & 2.97 & 1.11 & 2.08 & 1.57 & 2.73 \\
\hline 3 & 2.092 & 0.964 & 1.424 & 0.979 & 0.34 & 1.62 & 0.50 & 1.13 & 0.47 & 1.50 & 0.26 & 1.31 \\
\hline 4 & 1.918 & 0.969 & 1.249 & 0.983 & -0.59 & 1.79 & -0.14 & 0.97 & 0.52 & 1.26 & -0.27 & 1.23 \\
\hline 5 & 2.111 & 0.963 & 1.413 & 0.980 & 0.29 & 1.58 & 0.47 & 1.11 & 0.41 & 1.44 & 0.26 & 1.31 \\
\hline 6 & 2.404 & 0.950 & 1.407 & 0.979 & -1.48 & 2.55 & -0.73 & 1.55 & -0.10 & 1.35 & -0.22 & 1.43 \\
\hline 7 & 2.086 & 0.962 & 1.360 & 0.981 & -0.14 & 1.54 & 0.63 & 1.22 & 0.55 & 1.57 & -0.19 & 1.38 \\
\hline 8 & - & - & - & - & - & - & - & - & - & - & - & - \\
\hline 9 & 2.028 & 0.966 & 1.377 & 0.981 & -0.29 & 1.61 & 0.02 & 0.97 & 0.49 & 1.30 & 0.31 & 1.27 \\
\hline 10 & 2.116 & 0.963 & 1.457 & 0.979 & 0.36 & 1.49 & 0.57 & 1.15 & -0.28 & 1.53 & -0.81 & 1.03 \\
\hline 11 & 2.946 & 0.920 & 1.823 & 0.963 & 0.33 & 1.48 & 0.28 & 1.17 & 0.40 & 2.16 & 0.19 & 1.96 \\
\hline 12 & 2.737 & 0.932 & 1.810 & 0.964 & -0.27 & 1.22 & 0.09 & 1.04 & -0.30 & 2.41 & -0.22 & 2.13 \\
\hline 13 & 1.902 & 0.969 & 1.204 & 0.985 & -1.71 & 2.28 & -1.18 & 1.64 & -1.11 & 1.97 & -1.24 & 1.98 \\
\hline 14 & 3.492 & 0.885 & 2.337 & 0.938 & -1.36 & 2.35 & -0.91 & 1.86 & -0.32 & 1.50 & -0.47 & 1.75 \\
\hline 15 & 3.051 & 0.913 & 1.947 & 0.958 & -1.38 & 2.16 & -1.01 & 1.76 & -0.44 & 1.45 & -0.73 & 1.80 \\
\hline 16 & 1.953 & 0.970 & 1.379 & 0.981 & 0.10 & 1.62 & 0.35 & 1.03 & 0.52 & 1.47 & 0.29 & 1.30 \\
\hline 17 & 2.101 & 0.961 & 1.377 & 0.980 & 0.47 & 1.68 & 0.61 & 1.23 & 0.11 & 1.49 & 0.07 & 1.30 \\
\hline 18 & 1.866 & 0.972 & 1.340 & 0.983 & -0.55 & 2.03 & 0.00 & 1.01 & 0.93 & 1.53 & 0.27 & 1.27 \\
\hline 19 & 1.954 & 0.967 & 1.324 & 0.981 & 0.10 & 1.66 & 0.39 & 1.08 & 0.30 & 1.43 & 0.15 & 1.28 \\
\hline 20 & 1.645 & 0.979 & 1.301 & 0.984 & -0.69 & 2.11 & -0.09 & 1.01 & 0.88 & 1.55 & 0.22 & 1.24 \\
\hline 21 & 1.887 & 0.969 & 1.319 & 0.982 & -0.15 & 1.82 & 0.24 & 1.08 & 0.72 & 1.47 & 0.12 & 1.32 \\
\hline 22 & 1.675 & 0.976 & 1.260 & 0.983 & -0.56 & 2.00 & 0.01 & 1.02 & 0.71 & 1.41 & 0.11 & 1.26 \\
\hline 23 & 1.908 & 0.969 & 1.575 & 0.974 & -1.01 & 1.58 & -0.41 & 1.11 & -1.27 & 1.72 & -1.46 & 2.03 \\
\hline 24 & 2.180 & 0.958 & 1.753 & 0.963 & -1.87 & 2.66 & -0.67 & 1.57 & -0.56 & 2.31 & -0.93 & 2.04 \\
\hline 25 & 3.292 & 0.904 & 2.559 & 0.929 & 1.74 & 2.63 & 1.67 & 2.50 & -1.09 & 2.11 & -0.82 & 2.07 \\
\hline 26 & 1.993 & 0.970 & 1.509 & 0.980 & 0.52 & 1.73 & 0.63 & 1.20 & 0.25 & 1.46 & 0.22 & 1.33 \\
\hline 27 & 2.096 & 0.962 & 1.376 & 0.980 & 0.14 & 1.41 & 0.67 & 1.22 & 0.29 & 1.41 & 0.02 & 1.31 \\
\hline 28 & 2.097 & 0.962 & 1.433 & 0.978 & 0.47 & 1.43 & 0.87 & 1.35 & 0.02 & 1.35 & -0.14 & 1.34 \\
\hline 29 & 2.205 & 0.957 & 1.591 & 0.970 & 1.01 & 1.76 & 1.24 & 1.74 & -0.50 & 1.46 & -0.40 & 1.50 \\
\hline 30 & 2.694 & 0.937 & 1.914 & 0.961 & -2.51 & 3.20 & -1.46 & 2.08 & -0.43 & 1.56 & -0.95 & 1.78 \\
\hline 31 & 3.128 & 0.916 & 2.404 & 0.934 & -1.49 & 3.24 & -0.52 & 2.36 & -0.80 & 3.03 & -1.35 & 2.81 \\
\hline 32 & 1.709 & 0.976 & 1.348 & 0.980 & -2.88 & 3.29 & -1.81 & 2.10 & -0.38 & 1.37 & -0.41 & 1.36 \\
\hline 33 & 1.660 & 0.977 & 1.242 & 0.983 & -1.36 & 1.79 & -0.67 & 1.22 & -0.03 & 1.11 & -0.20 & 1.23 \\
\hline 34 & 2.790 & 0.928 & 2.112 & 0.950 & -1.34 & 2.53 & -0.58 & 1.89 & -0.35 & 1.59 & -0.65 & 1.91 \\
\hline 35 & 2.284 & 0.953 & 1.802 & 0.964 & -0.45 & 1.19 & -0.01 & 1.09 & -0.59 & 1.39 & -0.43 & 1.67 \\
\hline 36 & 2.077 & 0.963 & 1.329 & 0.981 & 0.19 & 1.56 & 0.44 & 1.09 & 0.45 & 1.43 & 0.29 & 1.32 \\
\hline 37 & 2.246 & 0.957 & 1.820 & 0.967 & 0.30 & 1.54 & 0.47 & 1.13 & 0.29 & 1.35 & 0.06 & 1.30 \\
\hline 38 & 1.888 & 0.967 & 1.591 & 0.969 & -3.47 & 3.78 & -2.89 & 3.21 & 0.53 & 1.55 & 0.20 & 1.38 \\
\hline 39 & 2.363 & 0.949 & 1.687 & 0.965 & -1.88 & 2.24 & -1.04 & 1.47 & 0.39 & 1.53 & 0.53 & 1.63 \\
\hline 40 & 2.228 & 0.958 & 1.833 & 0.969 & 0.37 & 1.58 & 0.49 & 1.14 & 0.16 & 1.41 & 0.06 & 1.33 \\
\hline 41 & 2.065 & 0.963 & 1.437 & 0.980 & 0.44 & 1.63 & 0.57 & 1.18 & 0.24 & 1.47 & 0.21 & 1.32 \\
\hline 42 & 2.681 & 0.935 & 1.784 & 0.965 & -0.93 & 1.56 & -0.16 & 1.03 & -0.62 & 2.24 & -0.17 & 1.97 \\
\hline 43 & 2.911 & 0.922 & 2.149 & 0.949 & -1.57 & 2.22 & -1.02 & 1.74 & -1.39 & 2.47 & -0.99 & 2.14 \\
\hline
\end{tabular}

Note: SSTs: sea surface temperature in the summer; SSTW: sea surface temperature in the winter. Dash indicates that no statistics were calculated.

Statistics are adjusted for degrees of freedom.

${ }^{b}$ Measure of difference is equal to the sum of the residuals squared, divided by the number of residuals minus two.

the equation worked across a broader span of Pleistocene time.

\section{INITIAL SPECIES SELECTION}

The starting point in SST equation development was the set of counts of all foraminiferal species in 191 core tops across the North Atlantic reported as equation F13 in Kipp (1976). Our goal was an equation usable across the range of oceanic environments from the northern subpolar gyre $\left(65^{\circ} \mathrm{N}\right)$ southward into the northern subtropical gyre $\left(30^{\circ} \mathrm{N}\right)$. Fortunately, several planktonic foraminifers occur in well-delimited regions and reach substantial abundances in the center of their geographic ranges. From the outset, we focused on four species: Neogloboquadrina pachyderma (the left-coiling form, hereafter designated s. for sinistral), Globigerina bulloides, Globorotalia inflata, and Globigerinoides ruber. The abundance maxima of these species in surface sediments span the range of environments of interest here (Fig 2; after Kipp, 1976).

Only one of these species involves significant taxonomic intergradations. Globigerina bulloides, a cold-water species, intergrades with Globigerina calida, a rare species widespread south of $40^{\circ} \mathrm{N}$, and with Globigerina falconensis, a more abundant species with a coherent core-top maximum near $40^{\circ} \mathrm{N}$. Our selection of only these four species to speed species identification is an $a$ priori constraint on the development of the equation.

The relative abundances of several of the species chosen are negatively correlated. This could mean that we have imposed too much redundancy and should have used species with weaker correlations to increase the total information content. As we will show later, however, the statistics for the chosen equation indicate substan- 


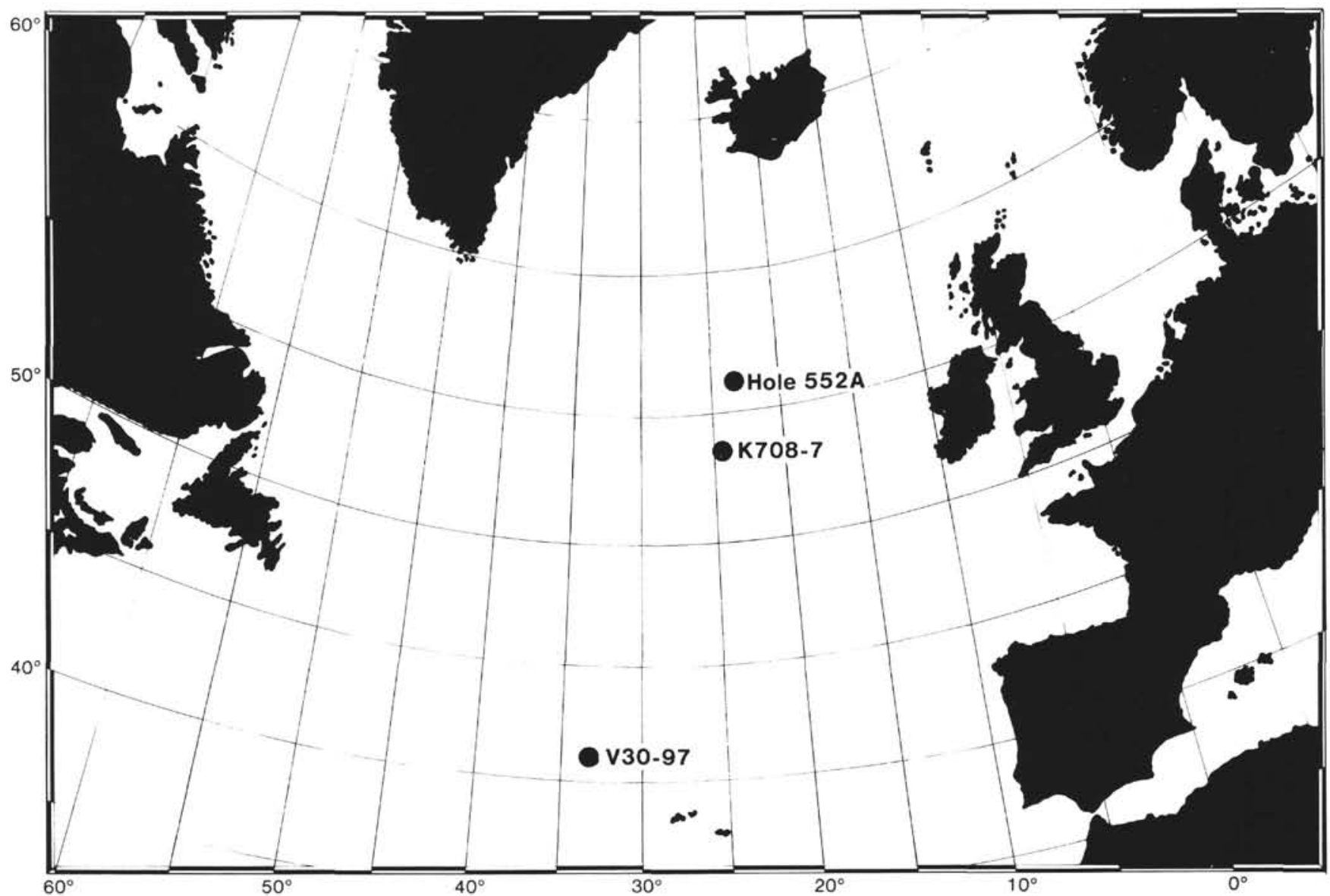

Figure 1. Location of cores used to evaluate downcore performance of equation $\mathrm{F} 13 \times 5$ developed in this study. Core $\mathrm{V} 30-97$ is from $41^{\circ} 00^{\prime} \mathrm{N}$, $32^{\circ} 50^{\prime} \mathrm{W}$; Core $\mathrm{K} 708-7$ from $53^{\circ} 56^{\prime} \mathrm{N}, 24^{\circ} 05^{\prime} \mathrm{W}$; and Hole $552 \mathrm{~A}$ from $56^{\circ} 03^{\prime} \mathrm{N}, 23^{\circ} 14^{\prime} \mathrm{W}$.

tial success despite losses to redundancy. Also, the four species have clear associations with discrete surface-water conditions, and their relative abundances should be environmentally useful independent of limitations on use of this transfer function back through time. Coulbourn et al. (1980) designated these four species, along with $N$. pachyderma (d.) and Globigerina quinqueloba, as key "eco-indicators" in the North Pacific.

The species culled from the equation account for a somewhat larger fraction of the fauna in most core tops than the four species that remain. Important species removed are Globigerina quinqueloba, with a distribution similar to G. bulloides, and Neogloboquadrina pachyderma (right-coiling or "d."), with a strong abundance maximum west of Great Britain (Kipp, 1976). There are good reasons for omitting both species. G. quinqueloba is small and dissolution-susceptible. The intergradation of $N$. pachyderma (d.) and Neogloboquadrina dutertrei through the "P/D" form (Kipp, 1976) is probably the most difficult problem in the taxonomy of modern planktonic foraminifers.

We obtained some benefit from the culled species without counting them individually by summing their abundances, calling the sum "Other," and entering it as a fifth "species" in the equation. Use of this lumped category "Other" may seem odd; however, its distribution within the geographic limits of the core-top data set for the equation ultimately chosen shows a fairly coherent abundance maximum ranging from southern subpolar to northern subtropical waters (Fig. 3A). Despite the admixture of many species, this distribution is similar to that of $G$. ruber (Fig. 2), except for a northward offset of the region of most rapid abundance change.

The relationship of "Other" and SST (Fig. 3B) is characterized by: (1) negligible values in the coldest waters; (2) rapidly changing abundances in cool subpolar waters; and (3) a broad plateau of maximum abundance in warmer waters to the south. The southern limit chosen for the equation eliminated the worst scatter of the percentage of "Other" against warm SST values at lower latitudes (Fig. 3).

\section{EQUATION DEVELOPMENT}

\section{Initial Culling of Equations}

We ran a total of 43 tests (Table 1), altering the following factors one at a time, or in various combinations: core-top samples included in the calibration data set (tests 1-5, 16-22, 24, 26, 36, 37, 40, 41); removing or adding species (tests 6-9, 23, 25, 30); use of the percent range transform from Imbrie and Kipp (1971) to express all surface-sediment species abundances as a percentage of their total range, rather than using untransformed species counts (test 10); prelinearizing the abundance trends 

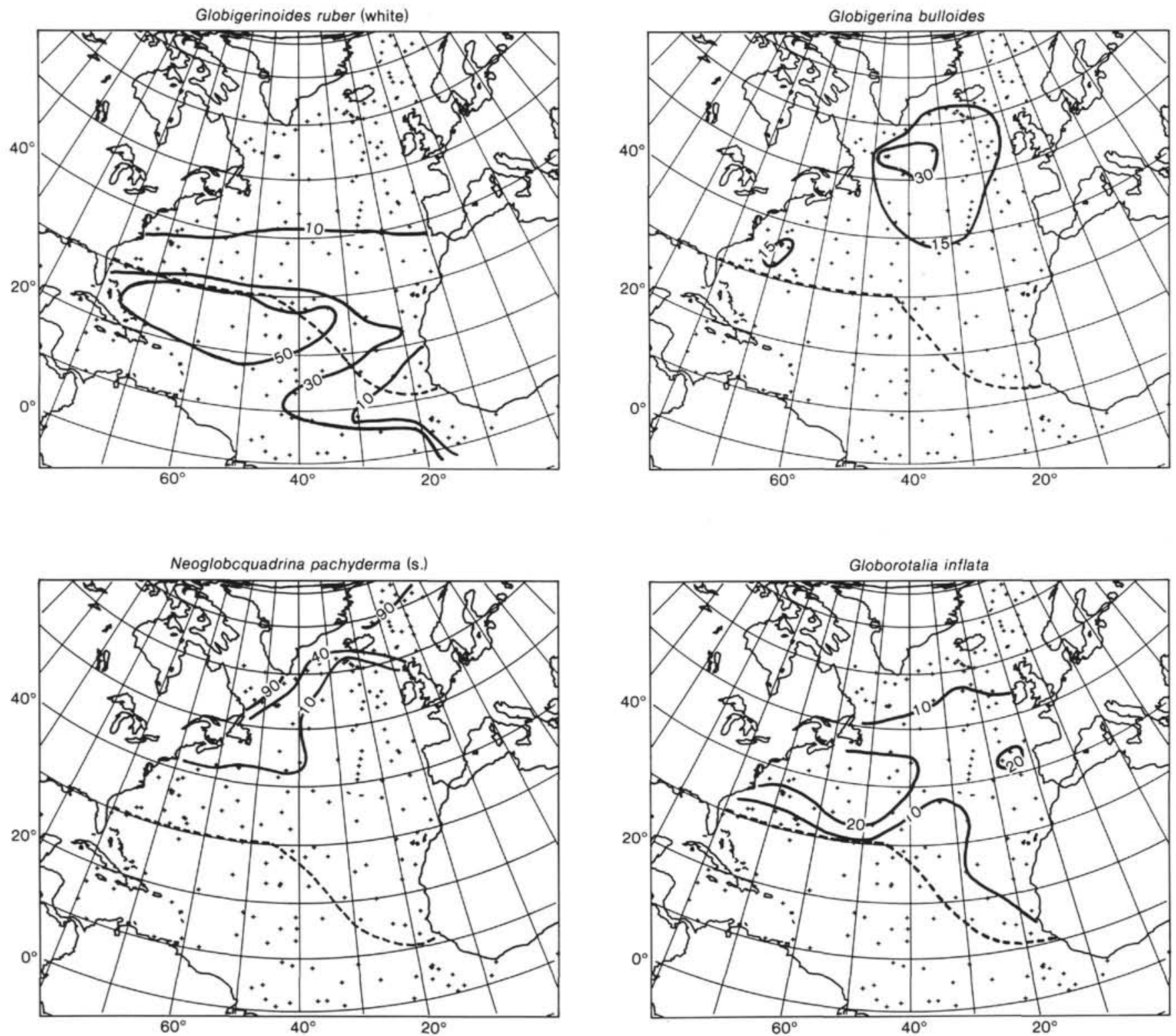

Figure 2. Geographic distribution (contours of percentage abundance) of four species chosen for use in transfer function F13 $\times 5$. Distributions based on 191 North Atlantic core tops reported in Kipp (1976). Dashed line shows southern limit of samples included in equation F13 $\times 5$.

of $G$. ruber before factoring to reduce scatter in the later regression against sea-surface temperature (tests 31-33); truncation of the factor analysis at a three-factor solution for the five variables (test 27); use of linear, rather than curvilinear, regression of factor scores against seasurface temperature (test 11); direct regression of species percentages against sea-surface temperature without factor analysis (test 34 ); and combinations of the above (tests 12-15, 28, 29, 35, 38, 39, 42, and 43).

About half of the tests failed badly on either the statistical measures of performance or in the visual match to downcore sea-surface temperature trends derived from reference equation $\mathrm{F} 13^{\prime}$. For many of these tests, there was an improved statistical performance in one season or in one downcore record, but in all cases there was a more severe degradation in the other season or in the other downcore records. The only tests to survive this initial culling were the 3 -factor solution (test 27), the regression of SST against unfactored species abundances (test 34), and a large number of tests with variable southern geographic limits to the calibration data set. The many kinds of failure included the following: excessively large core-top or downcore standard errors; a consistent shift of downcore SST estimates toward warm or cold values (the mean residuals in Table 2); inability to reproduce the coldest or warmest estimates in the downcore trends; and unrealistic exaggeration of extreme high or low SST values.

In test 23 , the "Other" category was found to be particularly critical in matching the downcore trends in Core K708-7; this category appears to provide needed information in the range of subpolar waters south of abundant $N$. pachyderma (s.) and somewhat north of the maximum of $G$. inflata. G. bulloides is abundant in this area, 

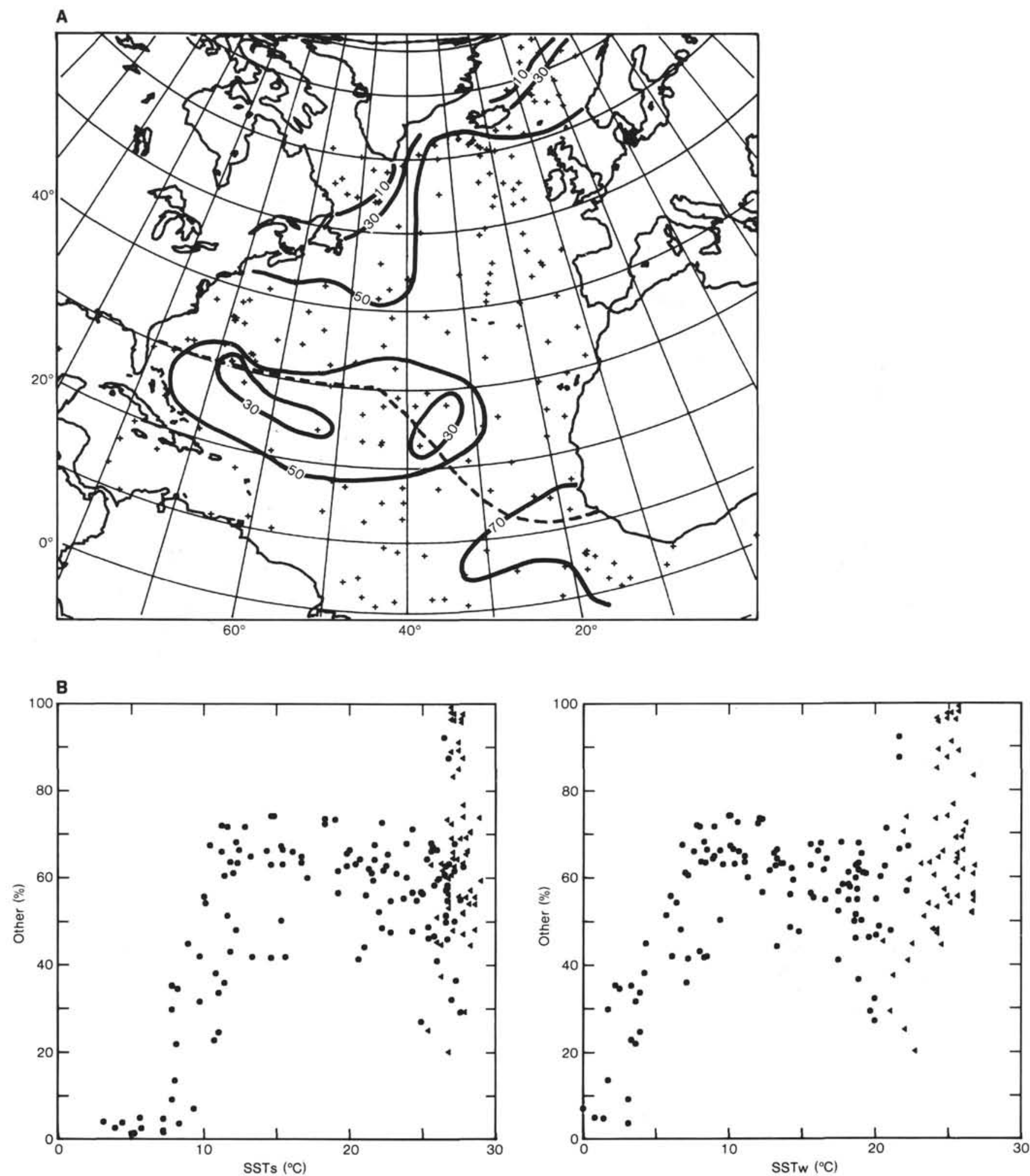

Figure 3. A. Geographic distribution (contours of percentage abundance) of lumped category "Other" used in new transfer function F13 $\times 5$. Distribution derived from core-top data in Kipp (1976). Dashed line shows southern limit of samples included in equation F13 $\times 5$. B. Percent abundance of lumped category "Other" from data in Kipp (1976) plotted against atlas values of winter and summer SST for each core location. Circles mark samples included in equation $\mathrm{F} 13 \times 5$; triangles are samples excluded. 
but its lack of strong percentage gradients across the region appears to reduce its usefulness in the equation.

In the remaining tests that gave reasonably good results on all measures of equation performance, the major variable was the southern geographic limit of samples included in the calibration data set. For these tests, a basic trade-off became apparent between the core-top statistics and the downcore statistics (and visual SST matches). Those tests with lowest standard errors of estimate for the core tops were not the tests with best downcore statistics and visual matches to reference equation F13'. We interpret this to mean that much of the statistical scatter in the relationship between core-top assemblages and atlas SST values reflects variability inherent in the imperfect linkage of these two parameters in the real world. This variability may derive from the impact of a number of environmental factors not closely related to sea-surface temperature; shifts in seasonal productivity may be particularly critical at high latitudes (Tolderlund and Bé, 1971; Loubere, 1982).

It follows that the core-top statistics may be improved by removing from the calibration data set those core tops that contribute to this scatter, but only at the expense of suppressing some of the real environmental information. As a result, these equations generate unrealistic SST estimates at some levels in the downcore reconstructions. Therefore we downgraded the importance of coretop statistics in the final stages of selecting an optimal equation, and we accepted somewhat higher standard errors of estimate. We stressed instead both the downcore statistical measures and the visual comparisons of downcore performance.

\section{Regions of Downcore Mismatch}

For the remaining equations with variable southern geographic limits, similar regions of downcore match or mismatch recurred in every comparison. To clarify discussion of these problem areas, we compare in Figure 4 the downcore SST estimates derived from the test equation ultimately selected (test 37 ) and those from reference equation $\mathrm{F} 13^{\prime}$.

The systematic mismatches in the remaining tests were concentrated at five levels in the two downcore SST records. Some of these mismatches persisted with little difference from equation to equation, but others varied significantly between equations (stages 7 and 13 in K708-7, stage 7 and transitions between stages 5 and 6 and stages 1 and 2 in V30-97) and formed the basis for the selection of the final equation. All of these mismatch levels are labeled with the names of the stages on Figure 4.

In Core K708-7, most of the stage 7 SST estimates (5.0 and $5.4 \mathrm{~m}$ depth in core) were too warm, especially in summer. This mismatch was large and varied little between equations. In the same core, stage 13 SST estimates $(10.6 \mathrm{~m})$ were consistently too cool for the summer season. For the winter season, some equations were able to match this part of the record.

In Core V30-97, the stage 6-5 and 2-1 transitions were generally poorly estimated, with the estimates too cold late in glacial stages $6(6.0 \mathrm{~m})$ and $2(0.5 \mathrm{~m})$ and too warm in the succeeding early interglacial stages $5(5.7 \mathrm{~m})$ and $1(0.3 \mathrm{~m})$. In both these cases, the degree of mismatch varied substantially between tests, and it was possible to select equations to minimize the offset.

In part, this was done by avoiding equations that exaggerated SST overshoots in both directions due to excessive culling of core tops. For example, we found that choosing a southern limit at or north of $30^{\circ} \mathrm{N}$ produced large SST overestimates, but selecting a limit farther south gave less extreme overshoots. We also attempted to balance the amount of overestimation of SST in either the warm or cold directions. This optimal balancing occurred in equations for which the calculated mean SST offset for the records as a whole was also minimized (Table 2). We were not able, however, to eliminate these mismatches entirely in any equation.

For the upper part of stage 7 in Core V30-97 (7.8 m), the equations yielded SST estimates that were generally too cool, giving the SST curve a somewhat different basic trend. The SST minimum in one of the fluctuations at the 23,000-yr. period was deepened considerably, and the following SST maximum was shifted higher in the core (Fig. 4).

All of the equations were more successful in estimating winter temperature values (SSTw) than summer values (SSTs), both in the core-top statistical measures and in the downcore statistical and visual measures of performance. The downcore SST mismatches for both seasons tended to occur at the same levels in the cores, but with greater exaggeration for the summer season. Because of the high correlation of winter and summer SST at middle and high latitudes today, we decided to focus on selecting the equation that produced the optimal downcore estimates for SSTw. As it turned out, this equation also did as well as any other in the estimates of the downcore SSTs.

\section{Final Geographic Culling of Core Tops}

After the earliest testing, we had used southern limits for the calibration data set in the range of latitudes between $20^{\circ}$ and $32^{\circ} \mathrm{N}$. This limit was chosen because the broad plateaus of abundance for percentages of $G$. ruber and "Other" in the warm waters at lower latitudes (Figs. 2, 3) suggested that little additional information could be gained at lower latitudes. This is also a reasonable choice in view of the unlikelihood of encountering fully tropical temperatures within the temperate North Atlantic during the Pleistocene.

Several additional insights developed from comparing the geographic truncations used in the remaining tests. Removing cores from the area of the Gulf Stream (test 26) significantly improved the core-top statistics but created very large SST overestimates in the stage 5 and stage 1 problem areas delineated in Figure 4, especially for the summer season (SSTs). In the Gulf Stream region, the high summer temperatures that normally produce high percentages of $G$. ruber alternate with unusually low winter temperatures that suppress $G$. ruber (Tolderlund and Bé, 1971). This reduces the contribution of $G$. ruber to the annually averaged flux of foraminifers 

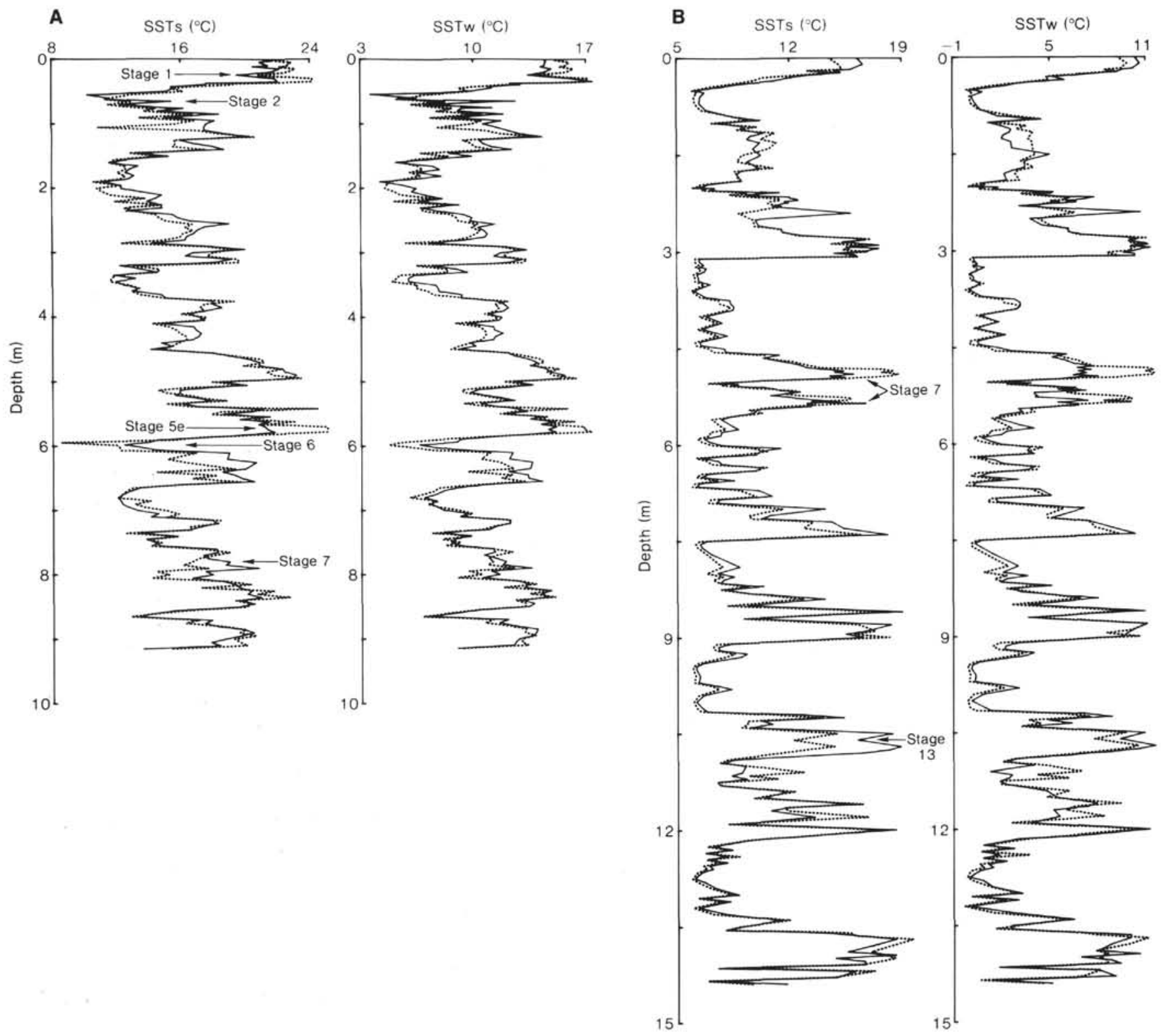

Figure 4. Estimated seasonal sea-surface temperature trends for two North Atlantic cores: A. V30-97, spanning the last 250,000 yr. B. K708-7, spanning the last $685,000 \mathrm{yr}$. Solid lines are estimates from transfer function F13'; dotted lines are estimates from new equation F13 $\times 5$. Levels of discrepancies between the two transfer functions are identified by the stage numbers.

to the seafloor compared to regions where winters are warm. Samples from this area with relatively low $G$. ruber percentages are paired against relatively high SSTs values, thus increasing the scatter in the regression of SSTs against the subtropical factor dominated by $G$. ruber.

As noted above, culling these samples improves the core-top statistics by reducing the scatter, but only at the expense of suppressing some of the information provided by this kind of environment. It also changes the regression line between the abundance of the $G$. ruber factor and SSTs; this makes the SSTs estimates oversensitive to higher percentages of $G$. ruber and causes the warm overshoots. There is no justification for culling this group of samples, which reflect high-seasonality con- ditions that could be prevalent during part of the Plẹistocene.

The measures of equation performance showed that the optimal location of a southern geographic limit west of $45^{\circ} \mathrm{W}$ is at $30^{\circ} \mathrm{N}$. This choice also makes good sense for oceanographic and biotic reasons. This is the latitude of the subtropical convergence, separating northern subtropical gyre waters that cool and overturn during winter from waters to the south where the upper-layer stratification persists throughout the year. This convergence is a detectable feature in the surface-sediment distribution of planktonic foraminifers (Ruddiman, 1969). The fauna south of the convergence is dominated by $G$. ruber, (percentages in excess of 50\%), a compact encrusted form not common elsewhere and probably resid- 
ually concentrated by dissolution of other more fragile species. There are thus obvious dangers in including these samples in the calibration of the equation.

In the Atlantic east of $20^{\circ} \mathrm{W}$, several tests showed that the optimal southern boundary to the core-top data set lies at $10^{\circ} \mathrm{N}$ and includes cores in the eastern boundary current regions of the Canary and Cape Verde islands. Again, removing core tops near these regions improved the core-top statistics but degraded the downcore matches, suggesting that information critical to the equation performance in this area should be included. In the Central Atlantic, the optimal southern limit ran diagonally across the ocean (Figs. 2, 3).

\section{EQUATION F13 $\times 5$}

Test 37 was the most successful of those examined (Fig. 4), and we name this new equation $\mathrm{F} 13 \times 5$. The factor analysis yielded the four-factor solution shown in Table 3, with $98.6 \%$ of the total information explained. The first three factors depend on single species or counting groups ("Other", N. pachyderma s., and G. ruber), and the fourth factor is a combination of $G$. bulloides and negative-loading $G$. inflata.

The core-top standard errors of estimate are about $50 \%$ higher and the multiple correlation coefficients somewhat lower than those for equation F13 (Kipp, 1976), but both measures still indicate good performance of the equation (Table 4). The terms of all coefficients in the summer and winter equations for $\mathrm{F} 13 \times 5$ are also listed in Table 4.

We have not plotted maps of the factor distributions; because of the single-species composition of the factors, their geographic distributions almost entirely repeat the species maps in Figure 2. We show in Figure 5 the SST residuals against observed (atlas) SST values to test whether the residuals are randomly distributed with respect to estimated SST. In general, the distribution looks random, but there is some tendency for positive residuals at the warm end of the range (observed SSTs > $25^{\circ} \mathrm{C}$, observed SSTw $>21^{\circ} \mathrm{C}$ ). This trend is more obvious in the summer than in the winter estimates, and it may be responsible for overestimates of SST during stages 5e and 1 (Fig. 4).

\section{FINAL EVALUATION OF EQUATION F13 $\times 5$}

\section{Spectral Power}

As noted earlier, the downcore match between SST values estimated by equation $\mathrm{F} 13 \times 5$ and those estimated

Table 3. F' matrix showing loading of species onto factors and the information explained.

\begin{tabular}{lrrrr}
\hline \multicolumn{1}{c}{ Species } & Factor 1 & Factor 2 & Factor 3 & Factor 4 \\
\hline Globigerinoides ruber (white) & -0.2089 & -0.0182 & 0.9643 & 0.1119 \\
Globigerina bulloides & 0.2113 & -0.0012 & -0.1042 & 0.8931 \\
Neogloboquadrina pachyderma (s.) & -0.0964 & 0.9946 & -0.0073 & 0.0078 \\
Globorotalia inflata & 0.2470 & -0.0041 & -0.0015 & -0.4311 \\
Other & 0.9173 & 0.1017 & 0.2433 & -0.0634 \\
Information explained by each & 59.935 & 21.143 & 14.807 & 2.703 \\
$\quad$ factor (\%) & & & & \\
Cumulative \% explained & 59.935 & 81.078 & 95.885 & 98.588 \\
\hline
\end{tabular}

Table 4. Coefficients of terms and intercept of equation F13 $\times 5$, standard errors of estimate, and multiple correlation coefficients for winter and summer seasons.

\begin{tabular}{|c|c|c|}
\hline & SSTs & SSTw \\
\hline $\begin{array}{l}\text { Multiple correlation coefficient } \\
\text { (adjusted for degrees of freedom) }\end{array}$ & 0.957 & 0.967 \\
\hline $\begin{array}{l}\text { Standard error of estimate }\left({ }^{\circ} \mathrm{C} \text { ) }\right. \\
\quad \text { (adjusted for degrees of freedom) }\end{array}$ & 2.246 & 1.820 \\
\hline Factor 1 (Other) & -14.26385 & -40.5976 \\
\hline Factor 2 (N.pachyderma s.) & -9.78345 & -66.33228 \\
\hline Factor 3 (G.ruber white) & 81.80910 & 21.00662 \\
\hline Factor 4 (G.bulloid.-G.inflata) & -3.04088 & 0.7058 \\
\hline Factor $1 \times$ Factor 2 & 13.31834 & 40.1515 \\
\hline Factor $1 \times$ Factor 3 & -4.74112 & 23.17750 \\
\hline Factor $1 \times$ Factor 4 & -26.11071 & -12.3294 \\
\hline Factor $2 \times$ Factor 3 & -51.89340 & 6.62362 \\
\hline Factor $2 \times$ Factor 4 & 10.81459 & 12.92838 \\
\hline Factor $3 \times$ Factor 4 & 41.83781 & 7.7486 \\
\hline Factor 1 squared & -4.05713 & 5.27042 \\
\hline Factor 2 squared & -8.05489 & 24.4654 \\
\hline Factor 3 squared & -78.18913 & -39.71202 \\
\hline Factor 4 squared & 11.69569 & -7.32533 \\
\hline Intercept & 23.61984 & 41.5199 \\
\hline
\end{tabular}

by reference equation $\mathrm{F} 13^{\prime}$ is excellent through the two long North Atlantic records (Fig. 4). Spectral analysis of the two SSTw records shows that the spectra from the two equations are also very similar (Fig. 6). For Core K708-7, there are no important differences between the two equations. For Core V30-97, the SSTw record from equation $\mathrm{F} 13 \times 5$ produces an increase in the absolute variance at all periods (Fig. 6, bottom left). But a plot of the total variance scaled to unit area shows that the increased power is distributed rather evenly across all periods and the two spectra are thus still very similar (Fig. 6, bottom right).

There is a slight increase of power at the 23,000-yr. period and decrease at the 100,000 -yr. period in the F13 $\times 5$ spectra from Core V30-97 (Fig. 6, bottom right). This may have occurred because the changes in amplitude of SST trends just before and after the last two deglaciations enhanced the "saw-toothed" shape that is the basic form of the 100,000-yr. cycle in many deep-sea records over the last 0.5 m.y. (Broecker and van Donk, 1970; Hays et al., 1976).

\section{Further Evaluation of Mismatch Regions}

For the limited regions of downcore mismatch in SST between the two equations, the simplest assumption would be that equation F13 $\times 5$ is in error. This is not certain, however, because reference equation F13' is not "ground truth," but simply one attempt to estimate unknown past values of SST.

To evaluate the SST mismatches in the problem areas in Core V30-97 near the last two deglaciations, we selected those samples for which the two equations gave the most discrepant SST estimates (Table 5). We then used two independent quantitative techniques to find those samples in the surface-sediment calibration set that most closely matched the problematical samples: (1) the "faunal index of affinity" (Sanders, 1958); and (2) a direct calculation of the correlation coefficient between 

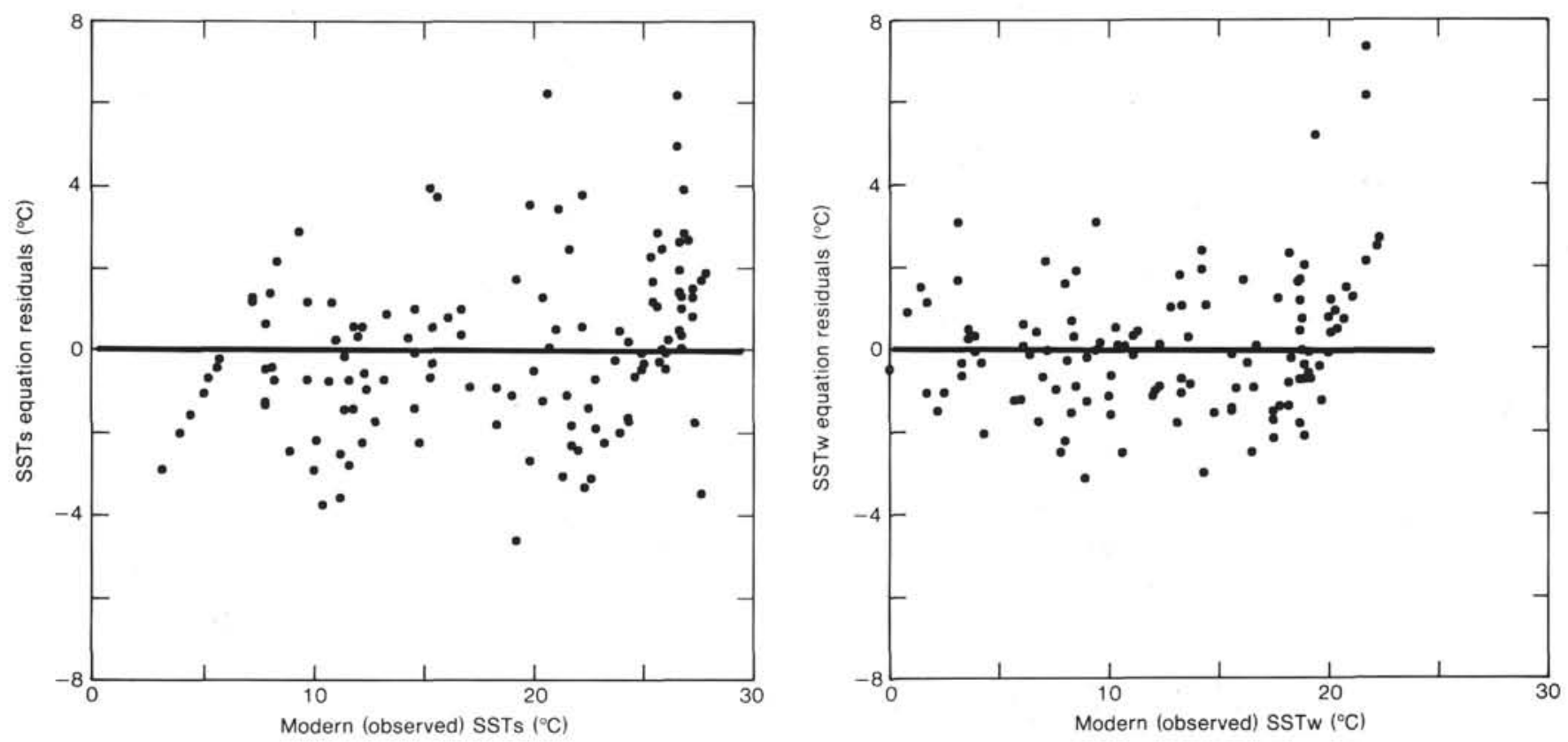

Figure 5. Residuals of estimated (versus observed) sea-surface temperature derived from equation F13 $\times 5$ against observed atlas sea-surface temperature for summer and winter seasons.

faunal compositions. Both techniques generally indicated the same core-top samples as most similar (Table 5).

For each surface sample selected by the measures of similarity, there is an associated atlas value of summer and winter SST overlying that core site. These are a guide to the range of likely SST values at the older levels in question. We used only the five most similar core-top samples listed in Table 5 as guidelines to the range of reasonable SST values at each older level. For the key winter season, equation F13 $\times 5$ matches the SST averaged for the most similar samples listed in Table 5 to within $1.5^{\circ} \mathrm{C}$ for every level except stage $5 \mathrm{e}$, where the values were $3.5^{\circ} \mathrm{C}$ too warm. At every level, at least one of the most-similar samples yields estimates within $1.2^{\circ} \mathrm{C}$ of the F13 $\times 5$ values. This analysis suggests that the F13 $\times 5$ SST estimates above and below the last two deglaciations were reasonable at all but the stage $5 \mathrm{e}$ level, where they were several degrees too warm.

For the area of disagreement in the upper part of stage 7 in core V30-97, the new equation appears to have accentuated somewhat the amplitude of the 23,000 -yr. SST cycle in this portion of the record. For the SST estimates originally produced by equation $\mathrm{F} 13^{\prime}$, this particular cycle was anomalously small in amplitude relative to adjoining cycles (see the filtered SST curve in fig. 8 of Ruddiman and McIntyre, 1981). The new equation reduces this "anomaly" by increasing the amplitude of this SST cycle.

In Core $\mathrm{K} 708-7$, the stage 7 SST estimates made by equation $\mathrm{F} 13^{\prime}$ 'suggest summer values considerably lower than in preceding or succeeding interglaciations, whereas the winter SST estimates are somewhat closer to the other interglaciations. The stage 7 SST estimates made by $\mathrm{F} 13 \times 5$ for both seasons closely resemble the preced- ing and following interglaciations; it is not clear which is the better set of estimates.

\section{Evaluation of Equation in a Longer Record}

An additional comparison was run on an older Pleistocene section (1.0-0.65 Ma) from Site 552, Hole 552A. These SST trends have been reported and analyzed for climatic significance by Ruddiman et al., in press). Most of the counts were tailored to equation F13 $\times 5$, with only the four species and "Other" recognized. Here we add selected full counts to compare the performance of equation $\mathrm{F} 13 \times 5$ in the older record against that of F13' (Fig. 7). Again, equation F13 $\times 5$ reproduces the basic trends estimated by equation F13' very closely. This validates the use of equation F13 $\times 5$ in this geographic region back to at least $1.0 \mathrm{Ma}$.

\section{SAMPLE COUNTING SIZE}

Finally, we tested for the effect of sample size on the precision of estimating SST. We chose three sediment samples representative of a wide range of late Pleistocene environments in the North Atlantic. We counted samples ranging in size between roughly 200 and 320 individuals, with five repetitions of each count (Table 6).

There was at most a very weak tendency for larger count sizes to yield smaller standard deviations, and in some cases the reverse trend occurred. The standard deviations in all cases were less than $0.7^{\circ} \mathrm{C}$, which is particularly small relative to the large-amplitude $\left(10-15^{\circ} \mathrm{C}\right)$ Pleistocene signals typical in the middle and high latitudes of the North Atlantic. Equation F13 gave similar standard deviations for the winter season in Caribbean sediments (Imbrie et al., 1973). We conclude that even count sizes as small as 200 to 250 individuals will yield 
FORAMINIFERAL TRANSFER FUNCTION FOR SUBSOLAR NORTH ATLANTIC
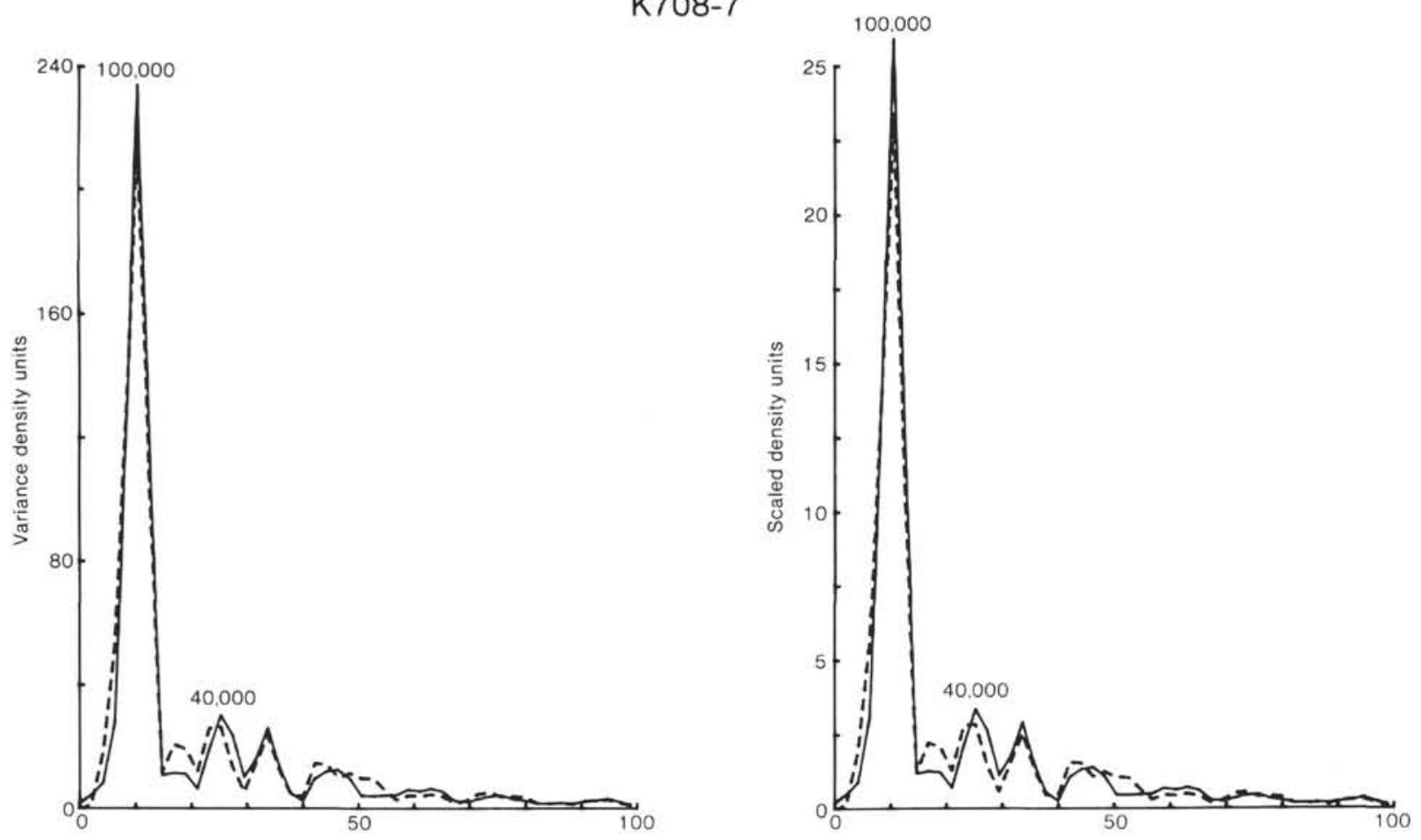

V30-97

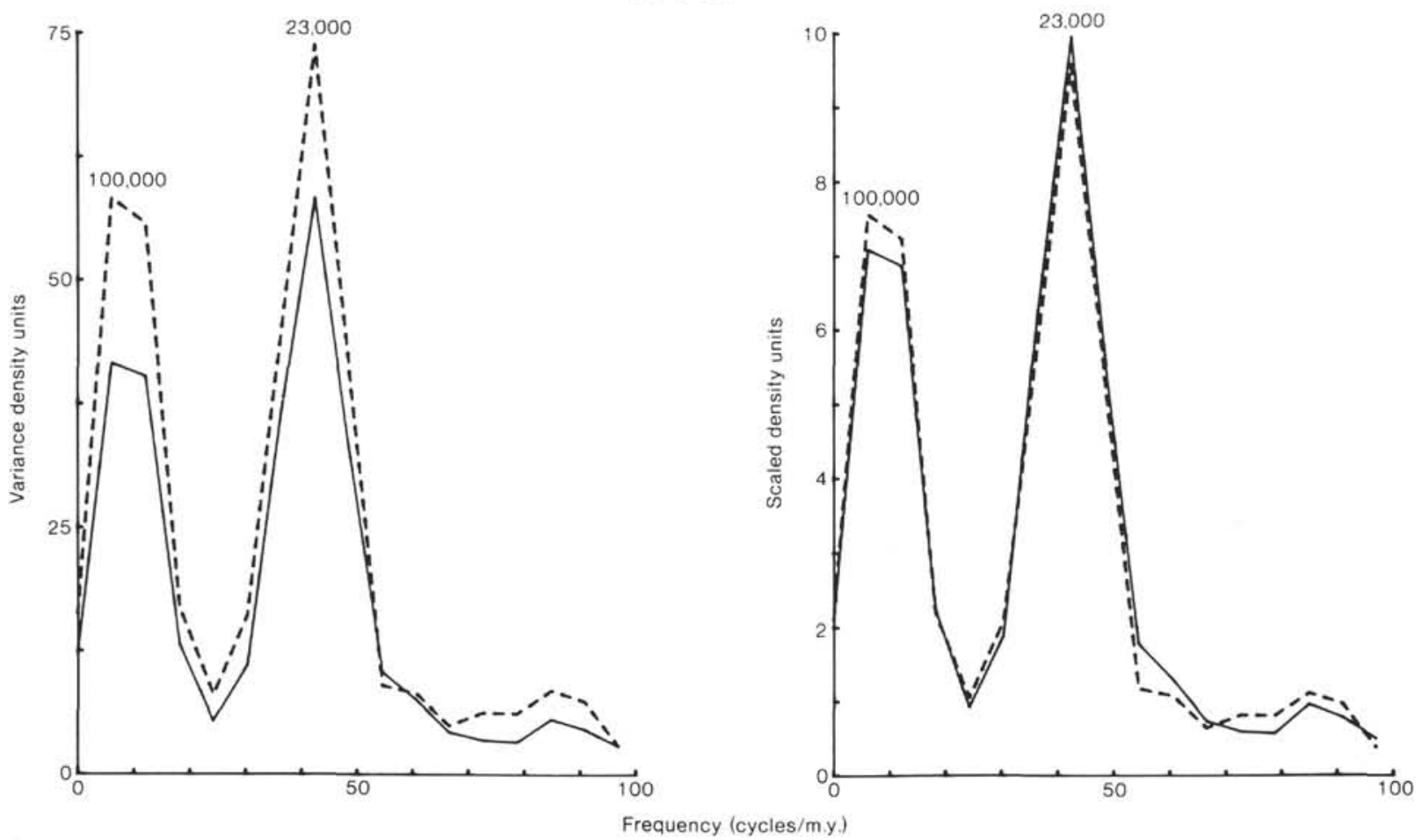

Figure 6. Spectral analysis of estimated winter sea-surface temperature record for Cores K708-7 (top) and V30-97 (bottom) from Figure 4. Solid lines are spectra from equation F13'; dotted lines are spectra from equation F13 $\times 5$. Spectra on left have linear varionce scales; spectra on right show total variance scaled to unit area.

1055 
Table 5. Evaluation of four V30-97 downcore samples showing excessively warm/cold temperatures just before/after the last two deglaciations (for each downcore sample, the five faunally most similar samples in the surface sediment data set are listed, along with atlas estimates of SST at those locations; two measures of faunal similarity are shown).

\begin{tabular}{|c|c|c|c|c|c|c|c|c|c|c|c|}
\hline \multirow{2}{*}{$\begin{array}{l}\text { V30-97 } \\
\text { sample } \\
\text { depth } \\
\text { (m) }\end{array}$} & \multirow[b]{2}{*}{$\begin{array}{l}\text { Faunal } \\
\text { measure }\end{array}$} & \multicolumn{2}{|c|}{ SST estimates } & \multicolumn{4}{|c|}{ Faunal index of affinity } & \multicolumn{4}{|c|}{ Correlation coefficient } \\
\hline & & SSTs & SSTw & $\begin{array}{c}\text { Core } \\
\text { samples }\end{array}$ & $\begin{array}{l}\text { Observed } \\
\text { SSTs }\end{array}$ & $\begin{array}{l}\text { Observed } \\
\text { SSTw }\end{array}$ & $\begin{array}{l}\text { Index of } \\
\text { affinity }\end{array}$ & $\begin{array}{c}\text { Core } \\
\text { samples }\end{array}$ & $\begin{array}{l}\text { Observed } \\
\text { SSTs }\end{array}$ & $\begin{array}{l}\text { Observed } \\
\text { SSTw }\end{array}$ & $\begin{array}{l}\text { Correlation } \\
\text { coefficient }\end{array}$ \\
\hline \multirow[t]{5}{*}{0.35} & & & & A $180-20$ & 24.3 & 17.5 & 72.3 & A $180-20$ & 24.3 & 17.5 & 0.874 \\
\hline & & & & V10-80 & 21.7 & 16.7 & 71.7 & V10-80 & 21.7 & 16.7 & 0.873 \\
\hline & & & & A $152-84$ & 20.0 & 13.3 & 70.3 & V4-32 & 21.7 & 15.6 & 0.861 \\
\hline & F13' & 22.0 & 17.4 & V4-32 & 21.7 & 15.6 & 69.2 & A $180-15$ & 23.7 & 15.8 & 0.841 \\
\hline & $\mathrm{F} 13 \times 5$ & 24.1 & 17.0 & V $27-143$ & 21.3 & 14.3 & 68.7 & V27-164 & 22.8 & 18.2 & 0.840 \\
\hline \multirow[t]{5}{*}{0.55} & & & & V23-16 & 15.6 & 6.1 & 77.6 & V $27-21$ & 10.7 & 3.3 & 0.931 \\
\hline & & & & V27-21 & 10.7 & 3.3 & 77.0 & V27-20 & 11.0 & 3.9 & 0.914 \\
\hline & & & & V $27-38$ & 11.8 & 8.0 & 76.6 & V $27-30$ & 8.1 & 3.6 & 0.906 \\
\hline & F13' & 10.2 & 3.6 & V27-32 & 8.9 & 4.3 & 76.4 & V27-32 & 8.9 & 4.3 & 0.902 \\
\hline & $\mathrm{F} 13 \times 5$ & 12.9 & 6.9 & V $27-20$ & 11.0 & 3.9 & 74.6 & V27-38 & 11.8 & 8.0 & 0.891 \\
\hline \multirow[t]{5}{*}{5.78} & & & & V29-177 & 21.1 & 14.2 & 76.2 & V23-13 & 22.8 & 14.8 & 0.859 \\
\hline & & & & V29-178 & 20.4 & 13.6 & 74.6 & A $180-15$ & 23.7 & 15.8 & 0.857 \\
\hline & & & & V $27-143$ & 21.3 & 14.3 & 74.5 & V29-177 & 21.1 & 14.2 & 0.853 \\
\hline & F13' & 21.8 & 15.1 & A $180-15$ & 23.7 & 15.8 & 74.3 & A164-17 & 26.6 & 18.7 & 0.812 \\
\hline & $\mathrm{F} 13 \times 5$ & 25.1 & 17.3 & V $23-13$ & 22.8 & 14.8 & 73.5 & V29-178 & 20.4 & 13.6 & 0.812 \\
\hline \multirow[t]{5}{*}{5.94} & & & & V $27-17$ & 15.3 & 9.4 & 81.3 & V $27-17$ & 15.3 & 9.4 & 0.950 \\
\hline & & & & V $23-22$ & 11.0 & 3.9 & 79.8 & V $23-22$ & 11.0 & 3.9 & 0.949 \\
\hline & & & & V $27-20$ & 11.0 & 3.9 & 71.2 & V $27-20$ & 11.0 & 3.9 & 0.866 \\
\hline & F13' & 14.0 & 9.0 & V27-114 & 12.0 & 7.0 & 68.4 & V27-114 & 12.0 & 7.0 & 0.835 \\
\hline & $F 13 \times 5$ & 8.5 & 5.5 & RE9-7 & 12.3 & 8.4 & 68.1 & V $27-21$ & 10.7 & 3.3 & 0.828 \\
\hline
\end{tabular}

acceptable precision with equation $\mathrm{F} 13 \times 5$ in the highlatitude North Atlantic.

\section{CONCLUSIONS}

Equation $\mathrm{F} 13 \times 5$ successfully reproduces the basic downcore SST trends earlier produced by equation F13' in subpolar North Atlantic records spanning the last million years. It also captures the distribution of spectral power at the critical orbital periodicities. Although the standard errors of estimates are $50 \%$ higher than those calculated by the standard equation, they remain acceptably small relative to the large SST variations characteristic of this part of the North Atlantic Ocean. Counts sizes as small as 200 to 250 individuals showed acceptable precision.

\section{ACKNOWLEDGMENTS}

We thank Barbara Molfino for advice on equation development, Beatrice Rasmussen for help with the manuscript, and Ted Moore for critical review. This research was funded by National Science Foundation proposal OCE82-19862 from the Submarine Geology and Geophysics Program. This is Lamont-Doherty Geological Observatory Contribution No. 3949.

\section{REFERENCES}

Broecker, W. S., and van Donk, J., 1970. Insolation changes, ice volumes and the $\delta^{18} \mathrm{O}$ record in deep-sea cores. Rev. Geophys. Space Phys., 8:169-198.

Coulbourn, W. T., Parker, F. L., and Berger, W. H., 1980. Faunal and solution patterns of planktonic foraminifera in surface sediments of the North Pacific. Mar. Micropaleontol., 5:329-399.

Hays, J. D., Imbrie, J. I., and Shackleton, N. J., 1976. Variations in the Earth's orbit: pacemaker of the Ice Ages. Science, 194:11211132.

Imbrie, J., and Kipp, N. G., 1971. A new micropaleontological method for quantitative paleoclimatology: application to a late Pleisto- cene Caribbean core. In Turekian, K. K. (Ed.), Late Cenozoic Glacial Ages: New Haven, CT (Yale Univ. Press), pp.71-181.

Imbrie, J., van Donk, J., and Kipp, N. G., 1973. Paleoclimatic investigation of a late Pleistocene deep-sea core: comparison of isotopic and faunal methods. Quat. Res., 3:10-38.

Kipp, N. G., 1976. New Transfer Function for estimating past sea-surface conditions from sea-bed distribution of planktonic foraminiferal assemblages in the North Atlantic. In Cline, R. M., and Hays, J. D. (Eds.), Investigation of Late Quaternary Paleoceanography and Paleoclimatology. Geol. Soc. Am. Mem., 145:3-42.

Loubere, P., 1982. Plankton ecology and the paleo-oceanographic-climatic record. Quat. Res., 17:314-324.

Ruddiman, W. F., 1969. Recent planktonic foraminifera: dominance and diversity in North Atlantic surface sediments. Science, 164: 1164-1167.

Ruddiman, W. F., and Glover, L. K., 1975. Subpolar North Atlantic circulation: 9300 yrs. B.P. Quat. Res., 5:361-389.

Ruddiman, W. F., and McIntyre, A., 1981. Oceanic mechanisms for amplification of the 23,000-year ice volume cycle. Science, 212: 617-627.

1984. Ice-age thermal response and climatic role of the surface Atlantic Ocean, $40^{\circ} \mathrm{N}$ to $63^{\circ} \mathrm{N}$. Geol. Soc. Am. Bull., 95: 381-396.

Ruddiman, W. F., Shackleton, N. J., and McIntyre, A., in press. North Atlantic sea-surface temperatures for the last $1.1 \mathrm{~m} . \mathrm{y} . \mathrm{Geol}$. Soc. London Spec. Publ.

Sanders, H. L., 1958. Benthic studies in Buzzards Bay-I. Animalsediment relationships. Limnol. Oceanogr., 3:245-258.

Shackleton, N. J., Backman, J., Zimmerman, H., Kent, D. V., Hall, M. A., Roberts, D. G., Schnitker, D., Baldauf, J. G., Desprairies, A., Homrighausen, R., Huddlestun, P., Keene, J. B., Kaltenback, A. J., Krumsiek, K. A. O., Morton, A. C., Murray, J. W., and Westberg-Smith, J., 1984. Oxygen isotope calibration of the onset of ice rafting in DSDP Hole 552A: history of glaciation in the North Atlantic Region. Nature, 307:620-623.

Tolderlund, D. S. rand Bé, A. W. H., 1971. Seasonal distribution of planktonic foraminifera in the western North Atlantic. Micropaleontology, 17:297-329.

Date of Initial Receipt: 24 June 1985

Date of Acceptance: 21 March 1986 
FORAMINIFERAL TRANSFER FUNCTION FOR SUBPOLAR NORTH ATLANTIC
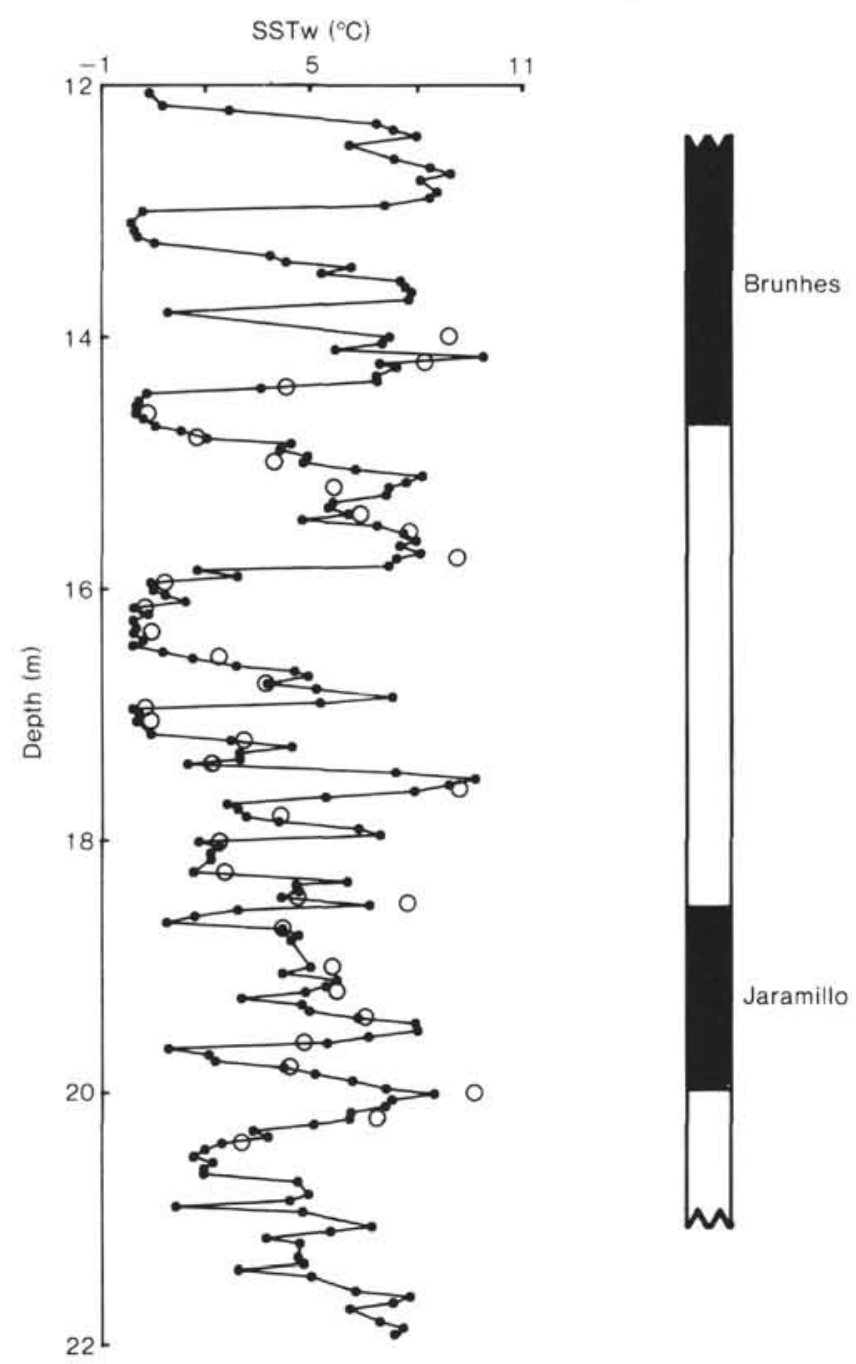

Figure 7. Estimated sea-surface temperature trends for North Atlantic Hole 552A in an interval from the lower part of the Brunhes Chronozone $(0.65 \mathrm{Ma})$ to just below the lower boundary of the Jaramillo Chronozone (1.0 Ma). Small closed circles joined by line are estimates from the new equation F13 $\times 5$; large open circles are estimates from equation $\mathrm{F} 13^{\prime}$. Hole 552A location is shown in Figure 1.
Table 6. Test of precision achieved using different count sizes (204-320 individuals) on the three samples spanning a wide range of estimated SST.

\begin{tabular}{|c|c|c|c|c|c|c|}
\hline \multirow{2}{*}{$\begin{array}{c}\text { Sample } \\
\text { (core-section, cm level) } \\
\text { (sub-bottom depth, m) }\end{array}$} & \multirow{2}{*}{$\begin{array}{l}\text { Number } \\
\text { of } \\
\text { counts }\end{array}$} & \multirow{2}{*}{$\begin{array}{l}\text { Mean } \\
\text { count } \\
\text { size }\end{array}$} & \multicolumn{2}{|c|}{ SSTs } & \multicolumn{2}{|c|}{ SSTw } \\
\hline & & & Mean & $\begin{array}{l}\text { Standard } \\
\text { deviation }\end{array}$ & Mean & $\begin{array}{l}\text { Standard } \\
\text { deviation }\end{array}$ \\
\hline Hole $552 \mathrm{~A}$ & 5 & 204 & 7.02 & 0.15 & 1.18 & 0.27 \\
\hline $4-2,60.5$ & 5 & 265 & 7.18 & 0.11 & 1.39 & 0.15 \\
\hline$(16.105)$ & 5 & 320 & 7.05 & 0.23 & 1.18 & 0.36 \\
\hline Hole 607 & 5 & 221 & 26.59 & 0.69 & 19.81 & 0.55 \\
\hline $2-5,53$ & 5 & 261 & 26.36 & 0.48 & 19.58 & 0.60 \\
\hline$(16.13)$ & 5 & 316 & 26.30 & 0.38 & 19.47 & 0.53 \\
\hline Hole 607 & 5 & 218 & 16.66 & 0.49 & 9.55 & 0.45 \\
\hline $3-2,106$ & 5 & 261 & 16.91 & 0.55 & 9.69 & 0.37 \\
\hline$(21.76)$ & 5 & 313 & 17.04 & 0.65 & 9.53 & 0.38 \\
\hline
\end{tabular}

